\title{
ANALISIS PENGARUH TEMPERATUR LINGKUNGAN, BERAT BADAN DAN TINGKAT BEBAN KERJA TERHADAP DENYUT NADI PEKERJA GROUND HANDLING BANDARA
}

\author{
Ratna Purwaningsih, Aisyah \\ Program Studi Teknik Industri, Universitas Diponegoro-Semarang \\ Jl. Prof. Sudarto,SH,Semarang
}

\begin{abstract}
Abstrak
Aktivitas ground handling bandara Ahmad Yani Semarang merupakan bagian yang berperan penting terhadap keselamatan penerbangan. Petugas ground handling, khususnya petugas apron bertanggung jawab melakukan persiapan sebelum take off ataupun pada saat landing. Penelitian ini bertujuan untuk mengetahui kondisi temperatur, berat badan pekerja dan tingkat beban kerja pekerja, mengetahui pengaruh temperatur, berat badan dan tingkat beban kerja terhadap denyut nadi 51 pekerja apron baik secara simultan ataupun individual dan menentukan faktor yang paling berpengaruh terhadap denyut nadi. Pengujian pengaruh hubungan variabel-variabel independen (temperatur lingkungan kerja, berat badan, tingkat beban kerja) terhadap denyut nadi dilakukan dengan menggunkan uji regresi berganda, uji t dan uji F. Persamaan regresi yang diperoleh adalah $\hat{y}=141,062-1,452$ x1 - 0,697 x2 + 11,681 x3. Berdasarkan uji $\mathrm{t}$ dan uji f yang telah dilakukan semua variabel independen mempunyai pengaruh yang signifikan terhadap variabel dependen baik secara simultan ataupun secara individual. Hasil perhitungan koefisien determinasi menunjukkan bahwa temperatur lingkungan mempunyai koefisien $\mathrm{R} 0,18$, berat badan 0,17 dan faktor tingkat beban kerja 0,424.Hal ini berarti bahwa tingkat beban kerja paling berpengaruh terhadap denyut nadi pekerja apron Bandara Ahmad Yani Semarang.
\end{abstract}

Kata kunci: temperatur; berat badan; beban kerja; denyut nadi; ground handling bandara

\section{Abstract \\ Analysis the effect of temperatur, body weights, and work load to heart pulse level of Airport ground handling worker}

Ground handling activities is a vital componen on safety flight. Ground handling officers, especially officers who responsible for apron preparation on takeoff or landing of a plane. This study aims to determine the effect of temperature, body weight and workload level to the heart pulse of 51 apron workers of Ahmad Yani airport Semarang either simultaneously or individually. Data processing and testing is done by using multiple regression test, $t$ test and $F$ test. Formulation as a result of regression analysis is $Y=141.062$ to $1.452 \times 1-0.69711 .681+x 2 \times 3$. Result ofe t test and F test show that all the independent variables have a significant influence on the dependent variable either simultaneously or individually. Calculation of the coefficient of determination indicates that environmental temperature has a coefficient $R$ 0.18, weight factor 0.17, and workload level 0.424. This means that the level of workload Ice the biggest influence to heart pulse of the apron workers Ahmad Yani Airport in Semarang

Keywords: temperature; body weight; work load; heart beat rate; Airport ground handling

\section{Pendahuluan}

Iklim kerja yang panas sudah menjadi salah satu penyebab yang sangat penting pada abad ini. Temperatur lingkungan yang ekstrim (panas) akan mempengaruhi respon fisiologis serta penurunan kinerja akibat dampak psikologis. Lingkungan kerja

\footnotetext{
${ }^{*}$ Penulis Korespondensi. email: ratna_ti2005@yahoo.com
}

Jurnal Teknik Industri, Vol. XI, No. 1, Januari 2016 panas akan memberikan beban tambahan bagi pekerja. Untuk mengeluarkan kelebihan panas dari tubuh, maka organ-organ tubuh bekerja lebih keras. Bila ini dikombinasikan dengan denyut nadi, maka beban yang diterima pekerja dapat menjadi sedemikian besarnya sehingga kelelahan akan terjadi dalam waktu yang pendek (Hendra, 2003). Iklim kerja yang panas atau tekanan panas dapat menyebabkan beban tambahan pada sirkulasi darah. Pada waktu melakukan pekerjaan fisik yang berat di lingkungan yang panas, maka darah 
akan mendapat beban tambahan karena harus membawa oksigen ke bagian otot yang sedang bekerja. Disamping itu harus membawa panas dari dalam tubuh ke permukaan kulit. Hal demikian juga merupakan beban tambahan bagi jantung yang harus memompa darah lebih banyak lagi.

Akibat dari pekerjaan ini, maka frekuensi denyut nadipun akan lebih banyak lagi atau meningkat. Peningkatan denyut nadi akan menyebabkan munculnya keluhan subjektif pada pekerja, sehingga dapat mengurangi performansi pekerja Haditia (2012), dalam penelitiannya mengenai analisis pengaruh suhu tinggi lingkungan dan beban kerja terhadap konsentrasi kerja juga menyatakan bahwa konsentrasi pekerja yang direpresentasikan melalui uji inspeksi visual secara signifikan dipengaruhi oleh faktor suhu lingkungan serta menyatakan bahwa faktor suhu dan beban kerja berkontribusi sebagai penyebab kecelakaan kerja.

Aktivitas fisik yang berat serta lingkungan kerja yang panas, menyebabkan beban fisik yang diterima tubuh petugas Apron, ground handling meningkat. Hal ini tentu saja berpengaruh terhadap beban mental petugas yang dapat beresiko terjadinya kelelahan kepada pekerja. Berdasarkan observasi lapangan yang telah dilakukan, diketahui tingginya suhu lingkungan kerja yang rata-rata berada diatas $30^{\circ}$ Celcius. Hal ini berakibat terjadinya gangguan kerja dan terjadinya penurunan performansi kerja serta menyebabkan kebutuhan energi yang diperlukan pekerja meningkat.

Menurut ketentuan yang ditetapkan oleh pemerintah yang berkaitan dengan temperatur tempat kerja, yaitu Peraturan Menteri Tenaga Kerja dan Transmigrasi PermenakerTrans PER.13/MEN/X/2011 tentang Nilai Ambang Batas untuk Iklim Kerja dan Nilai Ambang Batas untuk Temperatur Tempat Kerja, Ditetapkan : Nilai Ambang Batas (NAB) untuk iklim kerja adalah situasi kerja yang masih dapat dihadapi oleh tenaga kerja dalam pekerjaan sehari-hari yang tidak mengakibatkan penyakit atau gangguan kesehatan untuk waktu kerja terus menerus tidak melebihi dari 8 (delapan) jam sehari dan 40 (empat puluh) jam seminggu. NAB terendah untuk ruang kerja adalah $25{ }^{\circ} \mathrm{C}$ untuk beban kerja yang berat dan NAB tertinggi adalah $32,2{ }^{\circ} \mathrm{C}$ untuk beban kerja yang ringan, tergantung pada beban kerja dan pengaturan waktu kerja (Depnakertrans, 2011). Di Indonesia salah satu faktor yang menonjol sebagai penyebab gangguan kesehatan pekerja adalah lingkungan kerja yang panas.

Berdasarkan penelitian sebelumnya yang telah dilakukan oleh Fabri dan Pasha (2010), mengenai kebisingan dan tekanan panas dengan perasaan kelelahan kerja pada tenaga kerja, menyatakan bahwa tekanan panas merupakan salah satu faktor terjadinya perasaan kelelahan kerja yang dirasakan oleh tenaga kerja. Selain itu, pengaruh tekanan panas juga berdampak bagi kesehatan pekerja. Salah satunya adalah terjadinya kristalisasi urin pada pekerja yaitu berupa kristalisasi urin kalsium oksalat.
Tujuan penelitian ini adalah (1) Menemukan hubungan atau pengaruh dari variabel temperatur lingkungan kerja, berat badan, tingkat beban kerja terhadap denyut jantung pekerja beban kerja fisik, (2) Mengidentifikasi faktor yang paling berpengaruh terhadap beban kerja fisik.

\section{Tinjauan Pustaka \\ Tekanan Panas}

Tekanan panas merupakan kumpulan dari faktor lingkungan dan aktivitas fisik yang dapat meningkatkan jumlah panas di dalam tubuh. (Edwin L. Alpaugh, 1979 \& 1988) Faktor-faktor lingkungan meliputi temperatur udara, perpindahan panas radiasi, pergerakan udara, dan tekanan parsial uap air.

Terdapat tiga kategori beban kerja dalam Permenakertrans Indonesia. Beban kerja ringan didefinisikan sebagai beban kerja yang membutuhkan kalori sampai dengan 200 Kilo kalori/jam. Beban kerja sedang membutuhkan kalori lebih dari 200 sampai dengan kurang dari 350 Kilo kalori/jam. Beban kerja berat membutuhkan kalori lebih dari 350 sampai dengan kurang dari 500 Kilo kalori/jam.

\section{Beban Kerja}

Tarwaka (2004) menyatakan bahwa setiap beban kerja yang diterima oleh seseorang harus sesuai atau seimbang baik terhadap kemampuan fisik, kemampuan kognitif, maupun keterbatasan manusia yang menerima beban tersebut. Menurut Suma'mur (1984) bahwa kemampuan kerja sesorang tenaga kerja berbeda satu kepada yang lainnya dan sangat tergantung dari tingkat ketrampilan, kesegaran jasmani, keadaan gizi, jenis kelamin, usia dan ukuran tubuh dari pekerja yang bersangkutan. Secara umum hubungan antara beban kerja dan kapasitas kerja dipengaruhi oleh berbagai faktor yang sangat kompleks, baik faktor internal maupun faktor eksternal. Beban Kerja karena Faktor Eksternal adalah beban kerja berasal dari luar tubuh pekerja, meliputi:

1. Tugas-tugas (task), meliputi tugas bersifat fisik seperti, stasiun kerja, tata ruang tempat kerja, kondisi lingkungan kerja, sikap kerja, cara angkut, beban yang diangkat. Tugas yang bersifat mental meliputi, tanggung jawab, kompleksitas pekerjaan, emosi pekerja dan sebagainya.

2. Organisasi Kerja, meliputi lamanya waku kerja, waktu istirahat, shift kerja, sistem kerja dan sebagainya.

3. Lingkungan Kerja, ini dapat memberikan beban tambahan yang meliputi, lingkungan kerja fisik, lingkungan kerja kimiawi, lingkungan kerja biologi dan lingkungan kerja psikologis.

Faktor internal beban kerja adalah faktor yang berasal dari dalam tubuh akibat adanya reaksi dari beban kerja eksternal yang berpotensi sebagai stressor, yaitu (1) Faktor somatis seperti jenis kelamin, umur, masa tubuh, status gizi, kondisi kesehatan, dan sebagainya, (2) Faktor psikis seperti motivasi, persepsi, kepercayaan, keinginan, kepuasan, dan sebagainya. 
Beban kerja fisik, dapat berupa beratnya pekerjaan, seperti mengangkat, mengangkut, merawat, dan mendorong yang lebih menggunakan kemampuan otot sebagai sumber tenaganya (Manuaba, 2000). Penilaian beban fisik dapat dilakukan dengan dua metode secara objektif, yaitu penelitian secara langsung dan metode tidak langsung. Metode pengukuran langsung yaitu dengan mengukur oksigen yang dikeluarkan (energy expenditure) melalui asupan energy selama bekerja. Semakin berat kerja semakin banyak energi yang dikeluarkan. Meskipun metode dengan menggunakan asupan oksigen lebih akurat, namun hanya mengukur secara singkat dan peralatan yang diperlukan sangat mahal.

\section{Metodologi Penelitian}

Dalam penelitian ini, sistem yang akan dibahas adalah sistem pada ground handling Bandara Ahmad Yani Semarang dimana penelitian tersebut bersifat cross sectional atau hanya dilakukan dalam suatu waktu tertentu dengan pendekatan kuantitatif dan kualitatif. Terdapat 2 jenis data yang digunakan pada penelitian ini, yaitu data primer dan data sekunder. Data primer, berasal dari data kuantitatif hasil pengukuran yaitu berupa temperatur lingkungan kerja, data durasi aktivitas, dan denyut jantung/menit. Serta data kualitatif yang digunakan untuk memvalidasi data kuantitatif, berupa hasil dari interview kepada pekerja ground handling di wilayah apron. Untuk data sekunder diperoleh dari pihak bandara Ahmad Yani berupa data jadwal penerbangan dan berat badan responden.

Konsep yang digunakan dalam penelitian mengenai Pengaruh Temperatur Lingkungan kerja, berat badan dan tingkat beban kerja terhadap denyut nadi pekerja adalah sebagai berikut :

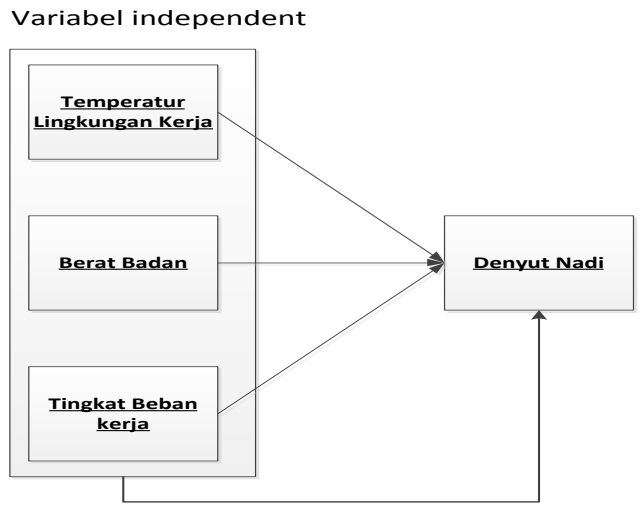

Gambar 1. Model Penelitian

Pengambilan sampel, dilakukakan secara purposive sampling dimana sampel dipilih berdasarkan penilaian peneliti bahwa dia adalah pihak yang paling baik untuk dijadikan sampel penelitiannya (Susanty, 2008). Populasi yang diteliti adalah populasi petugas ground handling yang berjumlah 75 orang. Sedangkan untuk penentuan ukuran pengambilan sampel, digunakan teknik purposive sampling
(Arikunto, 2006). Jumlah sampel yang diambil sebanyak 51 responden. Kriteria yang harus dipenuhi sebagai responden dalam penelitian adalah (1) Pekerja ground handling yang bertugas di apron dengan masa kerja minimal 1 tahun, (2) Tidak mengonsumsi alkohol (3) Tidak mengonsumsi kopi minimal 2 jam sebelum dilakukan pengukuran denyut jantung (4) Tidak mmiliki riwayat penyakit kardiovaskular, (5) Tidak dalam masa penyembuhan penyakit dan tidak dirawat di rumah sakit selama setahun terakhir.

Peralatan yang digunakan adalah thermometer untuk pengukuran suhu dengan kemampuan pengukuran pada kelembapan $10 \%$ to $95 \% \mathrm{RH}$ dan range suhu $-20^{\circ} \mathrm{C}$ to $60^{\circ} \mathrm{C}$. Sebelum pengukuran dipastikan bahwa Pada area tersebut terdapat sumber,area,atau proses kerja panas/dingin, data diambil tiap 15 menit selama operator bekerja. Alat ukur denyut jantung menggunakan pulse meter. Pengukuran denyut nadi ini dilakukan dengan cara menghitung denyut nadi pekerja pada saat sesudah kerja. Denyut nadi istirahat ditentukan pada saat operator akan mulai bekerja dan hanya diambil satu kali setiap harinya.

Lokasi yang digunakan untuk melakukan penelitian adalah Apron Bandara Ahmad Yani Semarang pada April sampai Juni 2013. Pengolahan data dilakukan dengan uji regresi linier majemuk yang diolah menggunakan script macro SPSS.

\section{Hasil dan Pembahasan}

Bandara ahmad Yani Semarang memiliki kesibukan penerbangan yang cukup padat. Untuk shift pagi, jumlah penerbangan (keberangkatan dan kedatangan pesawat) antara pukul 06.00 sampai dengan pulul 12.45 terjadi 17 penerbangan dengan waktu kerja apron yang bervariasi seperti ditunjukkan pada tabel 1 dan shift siang diberikan pada tabel 2 .

Tabel 1. Frekuensi penerbangan dan lama waktu kerja shift pagi

\begin{tabular}{ccc}
\hline $\begin{array}{c}\text { Waktu } \\
\text { Penerbangan }\end{array}$ & Frekuensi & $\begin{array}{c}\text { Lama Kerja } \\
\text { (menit) }\end{array}$ \\
\hline $06.00-07.00$ & 6 & $25-30$ \\
$08.30-09.30$ & 5 & $25-30$ \\
$10.00-11.00$ & 5 & $30-45$ \\
$12.05-12.45$ & 1 & 40 \\
\hline
\end{tabular}

Tabel 2. Frekuensi penerbangan dan lama waktu kerja shift siang

\begin{tabular}{ccc}
\hline $\begin{array}{c}\text { Waktu } \\
\text { Penerbangan }\end{array}$ & Frekuensi & $\begin{array}{c}\text { Lama Kerja } \\
\text { (menit) }\end{array}$ \\
\hline $12.45-13.20$ & 2 & 35 \\
\hline $14.00-15.00$ & 4 & $30-45$ \\
\hline $15.50-17.00$ & 5 & $30-45$ \\
\hline $18.00-19.30$ & 4 & $30-35$ \\
\hline
\end{tabular}


Jadwal operator melakukan handling bagasi tergantung pada jadwal kedatangan dan keberangkatan pesawat. Total waktu kerja hasil pengukuran untuk shift pagi adalah 530 menit untuk melayani 17 penerbangan. Sedangkan total waktu kerja shift siang adalah 480 menit dan melayani sebanyak 15 penerbangan.

Pengukuran denyut jantung dilakukan sebelum responden melakukan kerja yaitu pada pukul 05.30 untuk pekerja yang bekerja pada shift pagi (06.0013.00) dan pada pukul 12.00 untuk pekerja yang bekerja pada shift siang (13.00-20.00). Pengukuran dilakukan untuk mendapatkan denyut nadi istirahat. Kemudian ada pekerja yang bekerja full shift, yaitu pekerja yang bekerja di dua shift sekaligus, shift pagi dan shift siang. Selanjutnya denyut nadi juga diukur setelah pekerja melakukan kerja. Pengukuran denyut nadi dilakukan dengan menggunakan pulsemeter dengan waktu pengukuran selama 1 menit. Pada saat pengukuran responden tidak diperkenankan berbicara,bergerak atau melakukan aktivitas lain. Statistik deskriptif untuk hasil pengukuran denyut nadi pekerja diberikan pada tabel 3. Hasil pengukuran ini nantinya akan digunakan untuk menghitung energi yang dikeluarkan akibat kerja.

Tabel 3. Hasil Statistik Deskriptif Data Denyut Nadi Pekerja

\begin{tabular}{lcccccc}
\hline & \multicolumn{2}{c}{ Pagi } & \multicolumn{2}{c}{ Siang } & \multicolumn{2}{c}{ Full } \\
\cline { 2 - 7 } & 1 & 2 & 1 & 2 & 1 & 2 \\
\hline $\begin{array}{l}\text { Rata- } \\
\text { rata }\end{array}$ & 81,8 & 112,4 & 76,05 & 113,5 & 72,78 & 92 \\
Standar & 11,70 & 13,57 & 10,63 & 16,03 & 10,11 & 13,89 \\
$\begin{array}{l}\text { Deviasi } \\
\text { Min }\end{array}$ & 62 & 90 & 54 & 84 & 59 & 79 \\
Max & 101 & 137 & 103 & 135 & 90 & 117 \\
\hline \multirow{2}{*}{$*)$ 1 : denyut nadi sebelum kerja (nadi istirahat) } \\
$\quad *)$ 2: denyut nadi kerja
\end{tabular}

Pengukuran temperatur lingkungan kerja dan kelembaban udara dilakukan selama jam kerja. Pengukuran dilakukan setiap 5 menit dalam selang waktu 1 jam Untuk statistik deskriptif hasil pengukuran suhu dan kelembapan di lokasi penelitian bagi 51 responden diperoleh hasil seperti pada tabel 4 .

Tabel 4. Hasil Statistik Deskriptif Data Tekanan Panas

\begin{tabular}{lll}
\hline & Temperatur & Kelembaban \\
\hline Rata-Rata & 32,61 & 63,42 \\
Standar & 2,18 & 4,78 \\
Min & 28 & 54,9 \\
Max & 36 & 74,8 \\
\hline
\end{tabular}

Sebelum pengolahan data, data hasil observasi akan di uji dengan uji asumsi klasik untuk memenuhi persyaratan model regresi linear berganda (multiple regression) dimana dapat disebut sebagai model yang baik jika model tersebut memenuhi kriteria BLUE (Best Linear Unbiased Estimator). Pada penelitian ini terdapat 4 uji asumsi klasik yang digunakan yaitu uji multikolinearitas, heteroskesdastisitas, normalitas dan uji linearitas. Berdasarkan uji asumsi klasik yang sudah dilakukan, data yang diperoleh memenuhi syarat untuk dilakukan regresi.

Data beban kerja fisik diperoleh dengan melakukan pengolahan data denyut nadi istirahat dan denyut nadi kerja untuk mendapatkan jumlah konsumsi energi kerja dengan formulasi seperti berikut ini.

$\mathrm{Y}=1,80411-0,0229038 \mathrm{X}+4,71733.10-4$ $\mathrm{X}$.............(1)

Kemudian nilai yang diperoleh dirujuk pada klasifikasi atau kategori kerja dari ringan hingga berat dengan menggunakan standar kategori seperti diberikan pada tabel 5 .

Tabel 5. Klasifikasi Beban Kerja Fisik (NIOSH)

\begin{tabular}{lll}
\hline Kategori & $\begin{array}{l}\text { Denyut } \\
\text { Jantung } \\
\text { (Denyut/mnt) }\end{array}$ & $\begin{array}{l}\text { Pengeluaran } \\
\text { Energi } \\
\text { (Kkal/menit) }\end{array}$ \\
\cline { 2 - 3 } Sangat & $<60$ & $<2,5$ \\
Ringan & $60-100$ & $2,5-5,0$ \\
Ringan & $100-125$ & $5,0-7,5$ \\
Moderat & $125-150$ & $7,5-10,0$ \\
Berat & $150-175$ & $10,0-12,5$ \\
Sangat Berat & $>175$ & $>12,5$ \\
Berat Ekstrim & & \\
\hline
\end{tabular}

Penentuan beban kerja fisik dilakukan dengan mempertimbangkan pula tingkat beban kerja dan work rest regimen. Data waktu istirahat diperoleh berdasarkan tidak adanya aktivitas penerbangan baik berupa kedatangan ataupun keberangkatan pesawat terbang masing-masing shift kerja. Hasil pengukuran menunjukkan waktu istirahat untuk shift pagi selama 60 menit sedangkan untuk shift selama 65 menit.

Pada penelitian ini pendekatan untuk menghitung Tingkat beban kerja dengan estimasi kalori yang digunakan. Tingkat kalori dapat dihitung dengan mempertimbangkan jenis aktivitas yang dilakukan selama bekerja yaitu, duduk, berjalan, berdiri dan menggunakan kedua tangan.

Sayangnya metode ini kurang mempertimbangkan berat beban yang harus ditangani oleh pekerja, maka konversi nilai denyut jantung menjadi estimasi nilai kalori akibat kerja menjadi alternatif metode pengukuran beban kerja yang lebih baik. Namun, jika yang dicoba untuk dicari hubungannya adalah beban kerja dengan denyut jantung, pastilah formulasi 1 akan memberikan nilai korelasi yang baik antara ke dua variabel ini. Statistik deskriptif sebagai hasil pengukuran beban kerja diberikan pada tabel 6 dan gambar 2 . 
Tabel 6. Distribusi Beban Kerja Responden

\begin{tabular}{lrr}
\hline \multicolumn{1}{c}{ Beban kerja } & Jumlah & Persentase \\
\hline Ringan & 0 & 0 \\
Sedang & 1 & 1,96 \\
Berat & 33 & 64,71 \\
Sangat Berat & 17 & 33,33 \\
Jumlah & 51 & 100 \\
\hline
\end{tabular}

Gambar 2. Persentase Tingkat Beban Kerja.

\section{Hasil Regresi Linear Berganda}

Setelah dimiliki set data temperature, berat badan dan tingkat pembebanan kerja serta data denyut nadi pekerja, dilakukan pengolahan data dengan regresi linear berganda. Pengujian ini bertujuan untuk mengetahui hubungan antara temperatur lingkungan kerja, berat badan dan tingkat pembebanan kerja terhadap denyut nadi pekerja. Persamaan garis regresi yang diperoleh yaitu :

$\hat{y}=141,062-1,452 x 1-0,697 x 2+11,681$ $\mathrm{x} 3$............(2)

Koefisien regresi pada variabel temperatur bernilai $-1,452$ artinya jika variabel berat badan dan tingkat beban kerja tetap dan temperatur mengalami kenaikan $1 \%$ maka denyut nadi akan mengalami penurunan sebesar 1,452 denyutan per menit. Nilai variabel temperatur bernilai negatif, hal ini berarti terjadi hubungan negatif antara temperatur dengan denyut nadi, semakin naik temperatur maka denyut nadi tidak mengalami kenaikan. Hal ini bisa terjadi karena rentang temperatur lingkungan yang diukur tidak jauh berbeda dengan temperatur ruangan istirahat pekerja. Kondisi cuaca semarang yang tidak berada pada suhu normal juga dapat menjadi penyebab timbulnya hubungan yang negatif terhadap denyut nadi. Suhu maksimal lingkungan kerja pada saat pengukuran adalah $36^{\circ} \mathrm{C}$ sementara pada hari lain temperatur lingkungan dapat mencapai suhu $44^{\circ} \mathrm{C}$.

Koefisien regresi pada variabel berat badan bernilai -0,697. Pada persamaan ini berat badan menjadi faktor yang tidak berpengaruh secara signifikan terhadap denyut nadi. Koefisien regresi pada variabel tingkat beban kerja bernilai 11,681 artinya jika variabel berat badan dan temperatur tetap dan tingkat beban kerja mengalami kenaikan $1 \%$ maka denyut nadi akan mengalami kenaikan sebesar 11,681 denyutan per menit.

\section{Hasil Uji F}

Uji F dapat menunjukkan apakah semua variabel independen yang digunakan dalam model regresi mempengauhi variabel dependen secara bersama-sama atau tidak (Ghozali,2011). Uji statistik F digunakan untuk menunjukkan apakah semua variabel independen yang ada pada model regresi mempunyai pengaruh secara bersama-sama terhadap variabel dependen.

Hasil uji $F$ menunjukkan besarnya nilai signifikansi adalah 0,000 , sedangkan nilai $\mathrm{p}$ value yang digunakan adalah $>0,05$. Hal ini berarti bahwa variabel independen (temperatur lingkungan kerja, berat badan dan tingkat pembebanan kerja) berpengaruh secara simultan terhadap variabel dependen (denyut nadi).

Pengaruh variabel dependen secara individual terhadap denyut jantung juga perlu diketahui. Pengujian ini dilakukan dengan menggunakan uji t. Pengujian ini dilakukan kepada masing-masing variabel independen. Nilai $\mathrm{p}$ value yang digunakan adalah $>0,05$. Artinya jika nilai signifikansi $>0,05$ maka dapat dinyatakan variabel independen tersebut tidak mempunyai pengaruh secara individual terhadap variabel dependennya.

\section{Hasil uji t}

Untuk melihat perbedaan hasil pengukuran denyut nadi sebelum bekerja dengan denyut nadi setelah bekerja pada temperatur lingkungan yang panas, maka kedua hasil pengukuran dianalisis dengan menggunakan analisis statistik uji t. Rata-rata denyut nadi pada pengukuran pertama sebelum bekerja adalah 77,7255. Pada pengukuran berikutnya setelah terpapar panas didapat rata-rata sebesar 109,27. Terlihat perbedaan nilai mean antara pengukuran sebelum dan sesudah terpapar panas adalah - 31, 5445. Hasil uji statistik didapatkan nilai $\mathrm{p}=0,000(<$ 0,05). Berdasarkan nilai uji $F$ dapat diambil kesimpulan bahwa temperatur lingkungan merupakan penjelas yang signifikan terhadap kenaikan denyut nadi.

Uji t juga dilakukan untuk variabel dependen berat badan pekerja. Berdasarkan hasil uji $\mathrm{t}$ dapat disimpulkan bahwa berat badan merupakan penjelas yang signifikan terhadap denyut nadi. Berikutnya dilakukan juga uji $\mathrm{t}$ untuk mengetahui pengaruh variabel dependen beban kerja terhadap denyut jantung pekerja. Berdasarkan uji t dapat disimpulkan bahwa beban kerja merupakan penjelas yang signifikan terhadap denyut nadi. Uji t yang dilakukan memperoleh nilai signifikansi bernilai 0,000 untuk temperatur lingkungan kerja, berat badan dan tingkat beban kerja. Karena nilai signifikansi $0,000<0,05$, maka dapat disimpulkan bahwa temperatur lingkungan kerja, berat badan dan tingkat beban kerja berpengaruh signifikan secara individual terhadap denyut nadi.

\section{Nilai $R$ hasil regresi}

Berikutnya, untuk melihat dari ketiga variabel independen yang paling berpengaruh terhadap denyut nadi adalah dengan cara meregresikan ketiga variabel 
independen tersebut dan melihat nilai $\mathrm{R}$ nya. Hasil output spss untuk nilai $\mathrm{R}$ ini diberikan pada tabel 7 dan berupa ilustrasi gambar seperti pada gambar 3 .

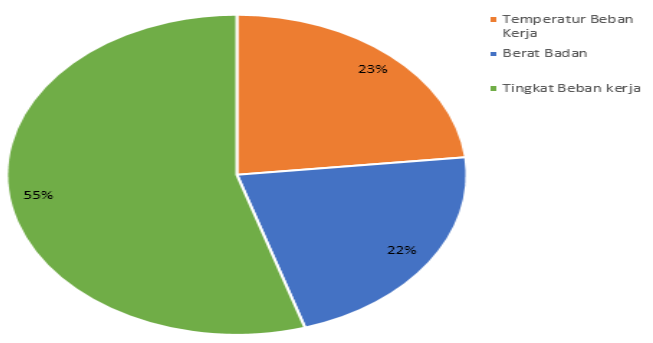

Gambar 3. Persentase Pengaruh Variabel Independen Terhadap denyut Nadi

Tabel 7. Output SPSS Perhitungan Nilai R

\begin{tabular}{lcccc}
\hline \multicolumn{1}{c}{ Variabel } & $\mathbf{R}$ & $\begin{array}{c}\mathbf{R} \\
\text { Square }\end{array}$ & $\begin{array}{c}\text { Adjusted } \\
\text { R Square }\end{array}$ & $\begin{array}{c}\text { Std. } \\
\text { Error } \\
\text { of the } \\
\text { Estimate }\end{array}$ \\
\hline Temperatur & $.180^{\mathrm{a}}$ & .032 & .012 & 16.45652 \\
$\begin{array}{l}\text { Berat badan } \\
\begin{array}{l}\text { Tingkat } \\
\text { pembebanan } \\
\text { kerja }\end{array}\end{array}$ & $.170^{\mathrm{a}}$ & .029 & .009 & 16.48553 \\
\hline
\end{tabular}

Tabel 7 menunjukkan bahwa nilai $\mathrm{R}$ untuk tingkat pembebanan kerja adalah yang paling besar dibandingkan dengan temperatur dan berat badan. Nilai $R$ untuk temperatur hanya bernilai 0,18 , berat badan 0,17 sedangkan untuk tingkat beban kerja 0,424 . Semakin mendekati angka 1 maka nilai $\mathrm{R}$ semakin kuat. Faktor yang paling berpengaruh adalah tingkat beban kerja. Gambar 3 menunjukkan bahwa variabel temperatur lingkungan kerja mempengaruhi denyut nadi sebesar $23 \%$, berat badan sebesar $23 \%$ sedangkan untuk tingkat beban kerja mempunyai pengaruh yang cukup besar terhadap denyut nadi yaitu sebesar $55 \%$.

Temperatur lingkungan kerja mempunyai nilai koefisien $\mathrm{R}$ yang kecil dikarenakan rata-rata temperatur lingkungan kerja pada saat dilakukan penelitian ini berada pada suhu $32,61{ }^{\circ} \mathrm{C}$, dengan standar deviasi 2,18 .

Sedangkan untuk berat badan pekerja, hanya 7 pekerja yang mempunyai kelebihan berat badan tingkat 1, sedangkan 41 responden mempunyai berat badan yang normal dan 2 orang pekerja memiliki masa tubuh di level kurus. Hal inilah yang diduga menyebabkan berat badan hanya mempunyai nilai koefisien $\mathrm{R}$ sebesar 0,17 .

Rekomendasi yang diberikan untuk pekerja apron untuk menjaga denyut nadi pada tingkat normal adalah dengan (1) pemberlakuan sistem rolling kerja, (2) pemberian jus jambu biji, (3) penyediaan minum yang cukup dan (4) penambahan AC di ruang istirahat pekerja.

\section{Kesimpulan}

Berdasarkan hasil penelitian yang dilakukan, dapat diketahui kondisi temperatur lingkungan kerja di Apron bandara Ahmad Yani Semarang berada diatas nilai ambang batas dengan rata-rata temperature yaitu $32,61^{\circ} \mathrm{C}$ dengan kelembaban $63,42 \mathrm{Rh}$. Pengolahan data dengan uji $\mathrm{F}$ menunjukkan bahwa temperatur lingkungan kerja, berat badan dan tingkat pembebanan kerja berpengaruh secara simultan terhadap denyut nadi. Ketiga faktor tersebut juga berpengaruh terhadap denyut nadi pekerja adalah secara individual.

\section{Daftar Pustaka:}

Alpaugh, Edwin L. (1979). Temperature Extreme. Fundamentals of Industrial Hygiene, second Edition, National Safety Council

Arikunto, Suharsimi. (2006). Prosedur Penelitian Suatu Pendekatan Praktik. PT. Rineka Cipta, Jakarta

Bernard, Thomas E., (1995). Thermal Stress. Fundamental of Industrial Hygiene, Fourth Edition. National Safety Council, Itasca, Illinois.

Fabri, Sukmal, Eko Pasha. (2010). Kebisingan dan Tekanan Panas Dengan perasaan Kelelahan pada Tenaga Kerja Bagian Drilling Pertamina EP Jambi. Politeknik Kesehatan jambi

Gozhali, Imam. (2011). Aplikasi Analisis Multivariate Dengan Program IBM SPSS 19. Badan Penerbit Universitas Diponegoro, Semarang

Gujarati, Damodar N. (2003). Basic Econometric Fourth Edition. USA: McGraw - Hill

Haditia, Iftitah Putri. (2012). Analisis Pengaruh Suhu Tinggi Lingkungan dan Beban Kerja Terhadap Konsentrasi Pekerja. Universitas Indonesia

Hendra. (2003). Faktor-faktor Yang Mempengaruhi Peningkatan Suhu Tubuh dan Denyut nadi Pada Pekerja yang Terpajan panas. Thesis Magister Kesehatan Keselamatan kerja. Universitas Indonesia

Keputusan Menteri Tenaga Kerja dan Transmigrasi NomorPer.13/MEN/X/2011 Tentang Nilai Ambang Batas Faktor Fisika Di Tempat Kerja, 2011, Jakarta: Departemen Tenaga Kerja dan Transmigrasi $R I$

Manuaba, I.B.A. (2000). Ergonomi Meningkatkan Kinerja Tenaga Kerja dan Perusahaan, Prosiding Simposium dan Pameran Ergonomi Indonesia, Bandung, ITB Press. p. 11

NIOSH (National Institute for Occupational Safety and Health). (1986). Criteria for a recommended standard, Occupational Exposure to Hot Environments, Revised Criteria

Suma'mur. (1984). Higiene Perusahaan dan Kesehatan Kerja. Gunung Agung, Jakarta

Tarwaka, Solichul H., Bakri A., dan Sudiajeng, Lilik. (2004). Ergonomi Untuk Kesehatan dan Keselamatan Kerja dan Produktivitas. UNIBA Press, Surakarta 